\title{
Amounts Mobilised from the Private Sector by Official Development Finance Interventions
}

Guarantees, syndicated loans and shares in collective investment vehicles

Julia Benn, Cécile Sangaré, Tomáś Hos, and Giovanni Maria Semeraro

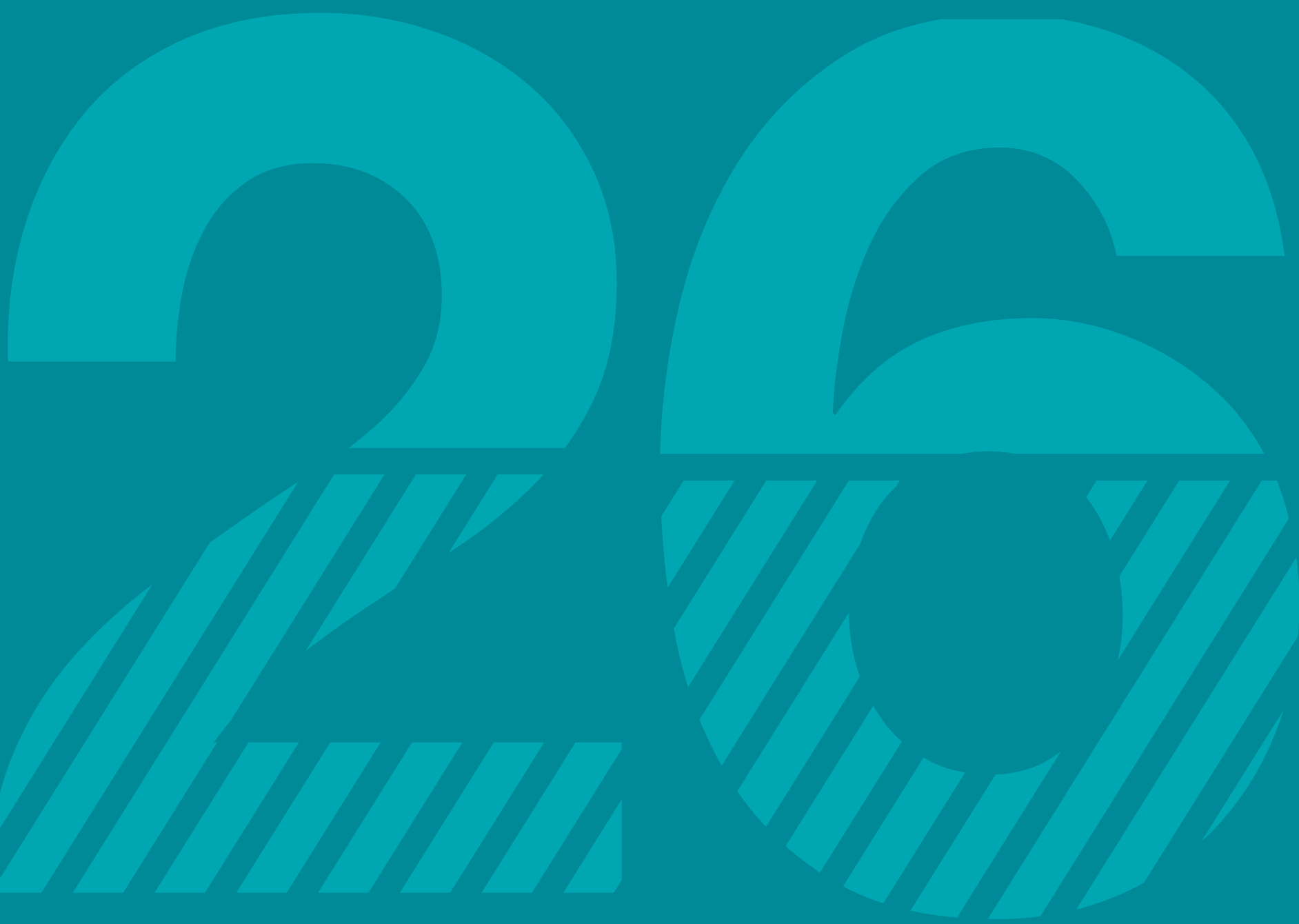

OECD DEVELOPMENT CO-OPERATION WORKING PAPER 26

Authorised for publication by Brenda Killen, Deputy Director, Development Co-operation Directorate 


\section{OECD Development Co-operation Working Papers}

OECD Working Papers should not be reported as representing the official views of the OECD or of its member countries. The opinions expressed and arguments employed are those of the authors.

Working Papers describe preliminary results or research in progress by the author(s) and are published to stimulate discussion on a broad range of issues on which the OECD works.

Comments on the present Working Paper are welcomed and may be sent to Julia.Benn@oecd.org- the Development Co-operation Directorate, OECD, 2 rue André-Pascal, 75775 Paris Cedex 16, France.

This document and any map included herein are without prejudice to the status of or sovereignty over any territory, to the delimitation of international frontiers and boundaries and to the name of any territory, city or area.

You can copy, download or print OECD content for your own use, and you can include excerpts from OECD publications, databases and multimedia products in your own documents, presentations, blogs, websites and teaching materials, provided that suitable acknowledgement of OECD as source and copyright owner is given. All requests for public or commercial use and translation rights should be submitted to rights@oecd.org. 


\section{9) OECD}

\section{AMOUNTS MOBILISED FROM THE PRIVATE SECTOR BY OFFICIAL DEVELOPMENT FINANCE INTERVENTIONS Guarantees, syndicated loans and shares in collective investment vehicles}

Julia Benn, Cécile Sangaré, Tomáš Hos, Giovanni Maria Semeraro

\section{ABSTRACT}

According to the 2015 DAC Survey on mobilisation, USD 36.4 billion was mobilised from the private sector in 2012-14 through official development finance interventions in the form of guarantees, syndicated loans and shares in collective investment vehicles (development-related investment funds). Overall flows followed an upward trend over the period covered by the survey, with guarantees mobilising the largest share (59\%). Multilateral development banks took the lead in mobilising finance mostly through guarantees, followed by the national development finance institutions. Middle-income countries received the largest share of the amount mobilised, mainly targeting the energy, industry and banking sectors. Of the total amount mobilised, $19 \%$ was climate-related, most of it focusing on climate change mitigation. This working paper provides more details about the Survey results.

\section{KEY WORDS}

Mobilisation, blended finance, development finance, leveraging, private sector development 


\section{TABLE OF CONTENTS}



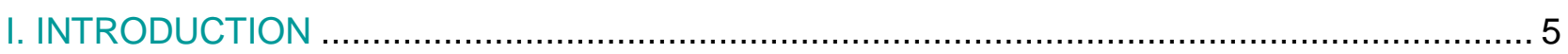







ANNEX 2. AMOUNTS MOBILISED BY RECIPIENT COUNTRY .......................................... 19

ANNEX 3. MEASURING MOBILISATION IN AN INTERNATIONAL STATISTICAL SYSTEM..... 22

ANNEX 4. MOBILISATION INSTRUMENTS METHODOLOGIES ............................................ 24

BOX 1: THE ROLE OF PRIVATE SECTOR MOBILISATION IN THE DEFINITION OF TOSSD ... 6

BOX 2. MOBILISATION VS. CATALYTIC EFFECT ….................................................. 8

AMOUNTS MOBILISED FROM THE PRIVATE SECTOR BY OFFICIAL DEVELOPMENT FINANCE INTERVENTIONS 


\section{EXECUTIVE SUMMARY}

According to the 2015 DAC Survey on mobilisation carried out by the OECD Development Assistance Committee (DAC), USD 36.4 billion was mobilised from the private sector during 2012-14 through official development finance interventions in the form of guarantees, syndicated loans and shares in collective investment vehicles (development-related investment funds). Over the period, the overall amount followed an upward trend, with guarantees mobilising the largest share. The multilateral development banks mobilised the most significant share of the total amount, followed by the national development finance institutions. In terms of recipients, the middle-income countries received the largest share of the amount mobilised, which were mainly targeted to the energy, industry and banking sectors. Approximately $18 \%$ of these amounts were labelled as climate-related, mostly in support of climate change mitigation. The Survey also aimed at piloting the methodologies developed for this first set of instruments. In that regard, it showed encouraging results - both in terms of coverage and quality of the information collected. Work will be pursued in 2016 by the DAC to develop methodologies for a broader range of leveraging instruments used in development co-operation. 


\section{LIST OF ABBREVIATIONS}

AFD

ASDB

CIV

DAC

DFI

EBRD

IADB

IFC

IFI

LDC

LIC

LMIC

MDB

MIGA

ODA

OPIC

PPP

Sida

SDGs

TOSSD

UMIC

USAID

USD

WP-STAT
French Development Agency

Asian Development Bank

Collective investment vehicle

Development Assistance Committee

Development finance institution

European Bank for Reconstruction and Development

Inter-American Development Bank

International Finance Corporation

International financial institution

Least developed country

Low-income country

Lower middle-income country

Multilateral development bank

Multilateral Investment Guarantee Agency

Official development assistance

Overseas Private Investment Corporation

Public-private partnership

Swedish International Development Cooperation Agency

Sustainable Development Goals

Total official support for sustainable development

Upper middle-income country

United States Agency for International Development

United States dollar

Working Party on Development Finance Statistics 


\section{INTRODUCTION}

Development finance debates have been focussing on how to mobilise further resources for development. The Sustainable Development Goals will set ambitious targets: even if official development assistance (ODA) will continue to be key in financing development, additional resources need to be mobilised to unleash the development potential of international financial flows. Those resources are also of great importance in the context of developed countries' commitment to mobilise USD 100 billion per year by 2020 for climate action in developing countries.

The OECD Development Assistance Committee (DAC) is the leading institution with regard to the measurement and monitoring of development finance, including ODA, other official and private flows. At their 2014 High Level Meeting, DAC members agreed to also report, as part of their regular data submission, private resources mobilised from the private sector by official development finance interventions and supported continued work to establish an international standard for measuring mobilisation. Thanks to its longstanding experience and know-how, the DAC has also been working since a couple of years on the development of a new statistical framework to monitor broader development finance in support to the SDGs - provisionally entitled total official support for sustainable development (TOSSD; See Box 1). In this context, the DAC work on mobilisation is carried out in close collaboration with the OECD-led Research Collaborative on tracking private climate finance. ${ }^{1}$

To better understand and measure the mobilisation effect of public interventions in support of private investment, the DAC Secretariat carried out a series of Surveys: in 2013, a first ever Survey on guarantee schemes $^{2}$ for development initiated the methodological work to measure the amounts mobilised from the private sector by this mechanism; in 2014, a second Survey aimed at reviewing the existing methodologies used by development finance institutions (DFIs) and enabled the Secretariat to set up key principles ${ }^{3}$ and derive methodologies for two additional instruments (syndicated loans and shares in collective investment vehicles). In 2015, a new Survey was carried out to i) pilot the methodologies developed to collect data on amounts mobilised through development guarantees, syndicated loans and shares in CIVs, and ii) collect data for the period of 2012-14.

This note provides a detailed analysis of the results of the 2015 DAC Survey on mobilisation ${ }^{4}$.

\footnotetext{
${ }^{1}$ See http://www.oecd.org/env/researchcollaborative

${ }^{2}$ See http://www.oecd.org/dac/stats/guarantees-for-development.htm.

${ }^{3}$ See http://www.oecd.org/dac/stats/principles-for-mobilisation.pdf.

${ }^{4}$ The results are also available online at: http://www.oecd.org/dac/stats/mobilisation-effect-of-public-developmentfinance.htm.
} 


\section{ANALYSIS OF THE SURVEY RESULTS}

The scope of the Survey was limited to amounts mobilised from the private sector as a result of official development finance interventions, including both international and domestic private funds. In order to avoid any double-counting, amounts mobilised from official sources were out of the scope of the Survey as these are already captured through the regular DAC data collection.

To be realistic and feasible, the methodologies used to capture amounts mobilised from the private sector ${ }^{5}$ followed a number of principles underpinning an international statistical system. They strove to be:

i. conservative, in terms of causality assumptions, as for some investments it can be quite complex to prove that private financiers would not have invested without the official intervention;

ii. fair, in terms of attribution (i.e. the amount that each official investor can claim to have mobilised if more than one official investor is involved), in order to avoid double-counting; and

iii. pragmatic, in terms of point of measurement and data availability. The methodologies built as much as possible on existing principles and definitions underlying DAC statistics ${ }^{6}$, in particular with regard to the point of measurement (commitments) and climate focus (Rio markers or MDBs' component approach).

\section{Box 1: The role of private sector mobilisation in the definition of TOSSD}

Given the broad and multiple financing challenges implicit in the Sustainable Development Goals (SDGs), it will be essential to exploit the already existing potential of official financial instruments and mobilise additional, and quite considerable, volumes of international development finance. The international context for this is promising: new sources of capital can be tapped, innovative financial instruments are widely available and investment opportunities abound. However, in order to realise this potential, incentives for mobilising and channelling "patient capital" - particularly from the private sector - need to be created.

DAC Ministers agreed in December 2014 to carry out analytical work and consult broadly across the international community to develop a new measurement framework for incentivising development finance from a wide variety of sources and actors in support of the ambitious SDGs. To this end, the new framework, provisionally entitled Total Official Support for Sustainable Development (TOSSD), would expand the current scope of statistical monitoring to include resources "beyond ODA", including nonconcessional development finance and international public finance that leverages private resources through blending operations, risk mitigation schemes and equity stakes. TOSSD could include private finance that is invested along with and mobilised by official development finance interventions in developing countries. The proposed statistical measurement framework would be key in this context, relying on the causality link between official and private investments and aiming at establishing a feasible, realistic and fair methodology. It is expected that TOSSD will be instrumental for informing both provider and recipient countries about the components of different financing packages including instruments used and how they are combined, thus encouraging transparency, broader learning about best practices and effectiveness in deploying a wide range of development finance from public and private sources. Work to develop the scope, boundaries and composition of the TOSSD framework will continue in 2016 with a wide range of development actors and stakeholders in a transparent, inclusive consultation process.

The Survey was launched in April 2015 through the DAC WP-STAT network of statistical correspondents, in collaboration with bilateral and multilateral DFIs known to use the instruments covered. The Survey

\footnotetext{
${ }^{5}$ See Annex.

${ }^{6}$ http://www.oecd.org/dac/stats/methodology.htm
} 
targeted 71 institutions, including bilateral and multilateral DFIs, development banks, aid agencies and public-private partnerships. The coverage of responses was satisfactory with 56 institutions having responded, representing the major international and bilateral DFIs.

Over the 56 institutions who responded, 29 institutions provided comprehensive data, which corresponds to a fair picture of the institutions known as potentially using the three mechanisms surveyed. However, some institutions were not able to share data explaining that detailed information on mobilisation was not readily available in their internal systems. For a few smaller institutions, the lack of resources was a major obstacle to participate in the Survey; other reasons for no reply included confidentiality concerns and the nondevelopmental motivation of financing through the three instruments surveyed. Overall, the challenges faced by some institutions for reporting this information reinforce the idea that a pragmatic approach should be adopted when developing methodologies for other instruments.

Figure 1. Rate of responses



Given that the DAC work on measuring mobilisation also aims to address the needs of the climate finance community, the Survey also sought information on the climate focus of the activities. Twenty-one (70\%) of the institutions which provided data to the Survey included climate reporting, covering $60 \%$ of the overall amount reported. 




\section{USD 36.4 billion mobilised from the private sector in $2012-14,59 \%$ of which through guarantees}

The Survey revealed that USD 36.4 billion were mobilised from the private sector in 2012-14 by official development finance interventions in the form of guarantees, syndicated loans and shares in CIVs (Figure 2). Guarantees were the main leveraging mechanism (59\% of the total amount mobilised). Over the 3 -year period, the amounts mobilised by these instruments followed an upward trend (an increase of $44 \%$ between 2012 and 2014), mainly attributable to syndicated loans for which the amounts mobilised quadrupled since 2012. 
Figure 2. Amount mobilised by instrument, USD billion


Note: Differences in the charts are due to rounding.

\section{Breakdown by provider: multilateral development banks were the main actors}

More than half of the total amount mobilised related to programmes by multilateral organisations, particularly multilateral development banks (MDBs). MIGA was the main actor, mobilising $41 \%$ of the amount attributable to MDBs, followed by IFC (19\%), EBRD (11\%) and other institutions. The main instruments used by these institutions were guarantees (49\%) - reflecting MIGA's portfolio - and syndicated loans (39\%), while shares in CIVs represented only $13 \%$ of the amounts they mobilised from the private sector (Figures 4 and 5).

As shown in Figure 3, the main bilateral actors in this area were the United States (USD 10 billion, 59\%), the United Kingdom (USD 2.7 billion, 16\%) and France (USD 1.6 billion, 10\%). Considering bilateral DFIs, OPIC was by far (50\%) the biggest player, followed by the CDC Group (15\%), USAID (6\%). (See figures 4 and 5.) Here again, a large share of the amounts mobilised was through guarantees (especially by OPIC). Shares in CIVs were the second leveraging instrument for bilateral actors (mainly from the United Kingdom) while syndicated loans played the smallest role. 
Figure 3. Top provider countries, USD billion

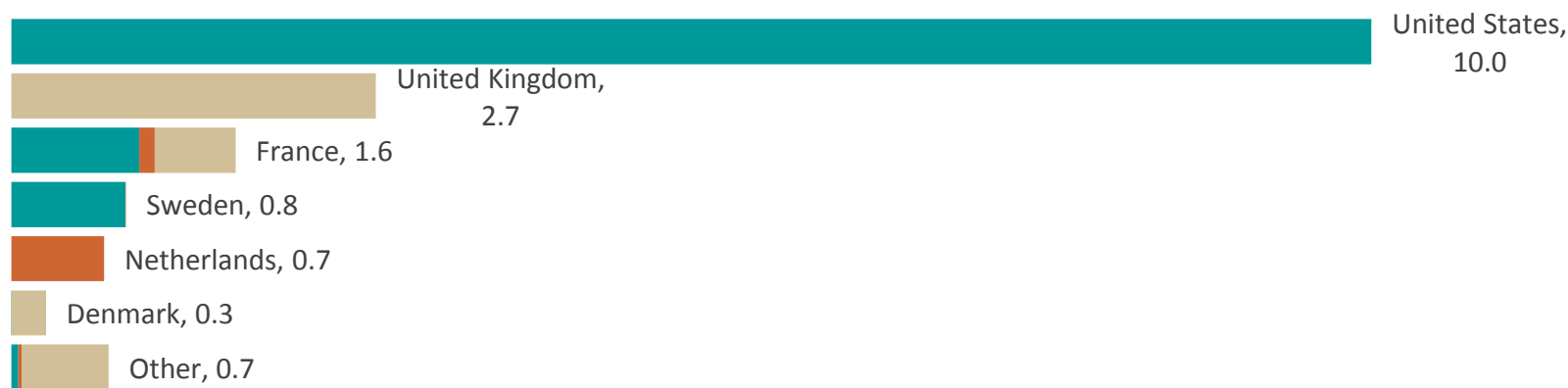

Guarantees Syndicated loans Shares in CIVs

Figure 4. Type of institution, USD billion



Development Finance Institutions, 12.8
Multilateral Development Banks, 18.8

Development Banks, 2.7

Aid agencies, 1.2

Public-private

Partnerships, 0.8

Other, 0.2

- Guarantees Syndicated loans $\quad$ Shares in CIVs

Figure 5. Top provider institutions, USD billion Multilateral institutions ${ }^{1}$

Bilateral institutions



MIGA, 8.0

IFC, 3.7

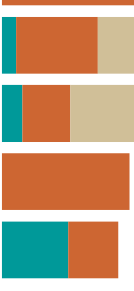

EBRD, 2.1

AsDB, 2.1

IADB, 1.9

Other, 1.8

Guarantees



OPIC, 8.3



AFD, 0.9

Sida, 0.8

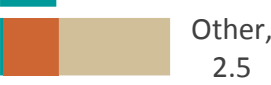

2.5

Syndicated loans
Shares in CIVs

1. IFC does not treat guarantees as a mobilisation instrument in its internal reporting system. Guarantees appear directly on IFC's

PRIVATE FINANCE MOBILISATION BY OFFICIAL DEVELOPMENT FINANCE INTERVENTIONS

Guarantees, syndicated loans and collective investment vehicles 


\section{Breakdown by recipient region and country: the top-recipient region was Africa}

Private finance mobilised through the three instruments was mainly benefiting Africa (29\%, Figure 6), followed by Asia (27\%) and America (21\%). The European region, comprising of 10 developing countries, received $15 \%$ of the overall amount mobilised. For a significant share of the amounts mobilised (7\%) the amounts mobilised were reported without geographic allocation.

Figure 6. Regional distribution

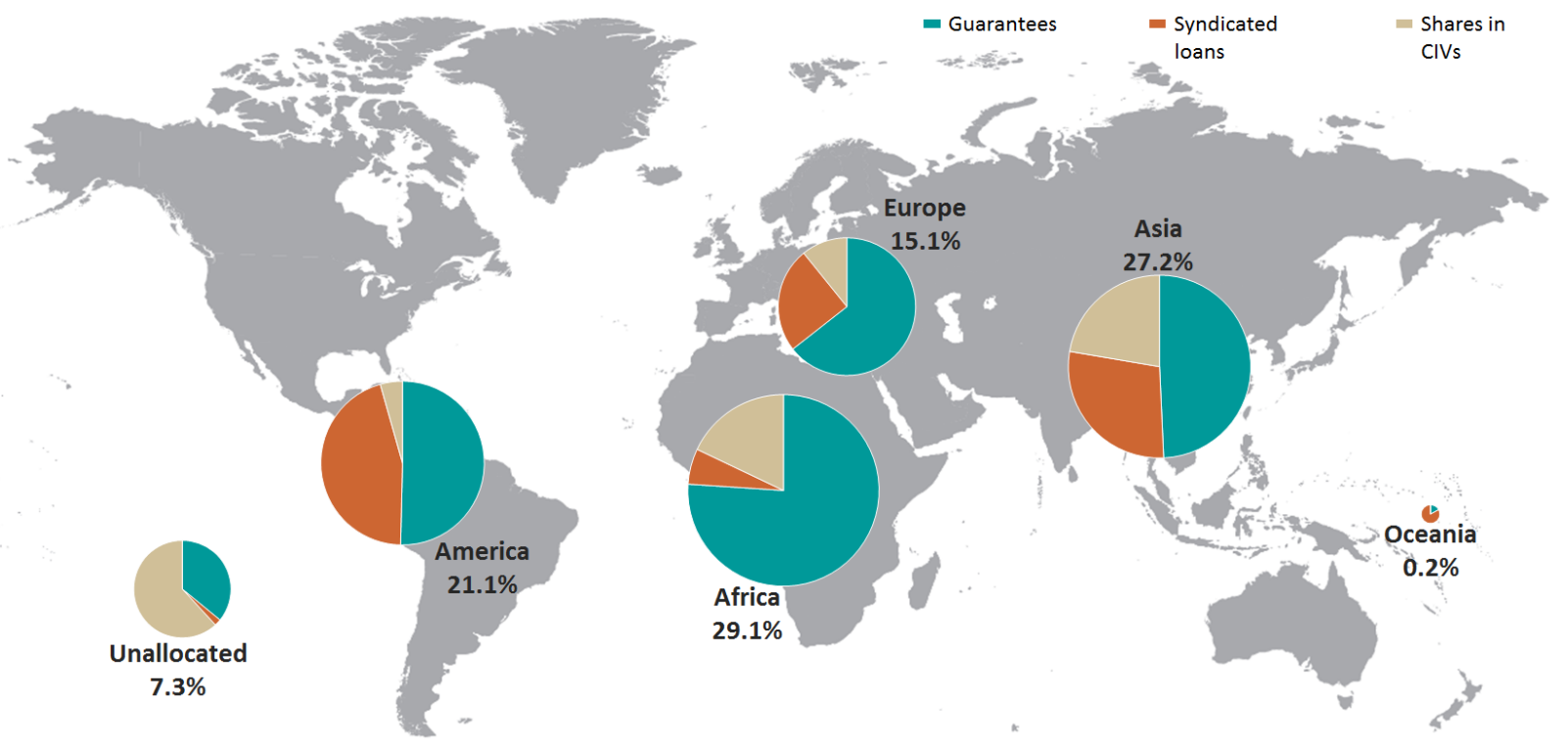

Figure 7. Geographical allocation and top ten recipient countries

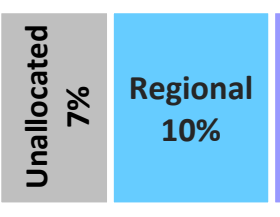

2.6

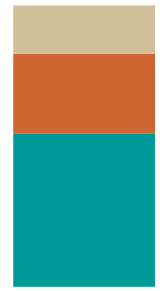

Turkey
1.4

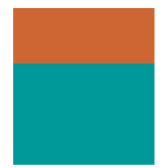

Chile



USD 13.0 billion

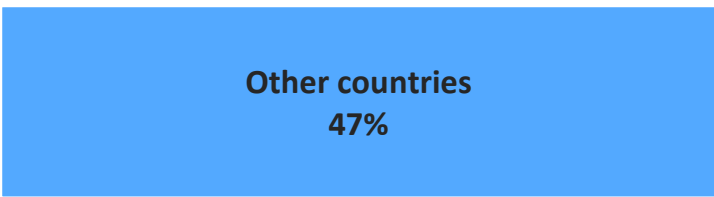

$$
47 \%
$$

1.3

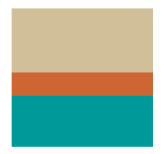

India
1.2

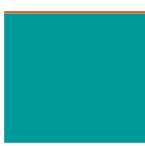

Pakistan

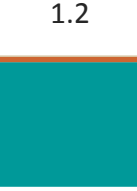

Serbia

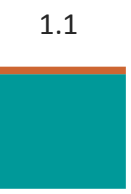

Côte d'Ivoire
1.1

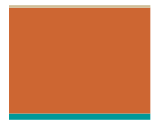

China

(People's Republic of)
1.0

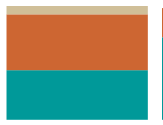

Brazil
1.0

1.0

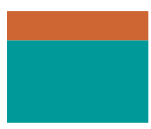

Jordan

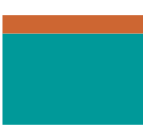

Ghana 
As regards the recipient country breakdown, amounts mobilised were distributed relatively homogeneously. The top beneficiary was Turkey (7.1\%), followed by Chile, India, Pakistan, Serbia, Côte d'Ivoire, China (People's Republic of), Brazil, Jordan and Ghana (Figure 7). Together these ten countries received approximately one-third of the total amounts mobilised, mainly through guarantees. In the case of Pakistan, Serbia and Côte d'Ivoire, almost all of the amounts of private investment mobilised were attributable to guarantees (Figure 7). Syndicated loans were the major leveraging instrument for projects in China (representing 93\% of the private funds mobilised), but it was dominant also in Brazil (49\%), Chile (35\%), Turkey (28\%) and Jordan (26\%). Shares in CIVs were mainly used to mobilise private funds for activities in India (46\%) and Turkey (17\%). A large share of the amounts mobilised through shares in CIVs (61\%) was reported under "Africa, regional".

In addition, the Survey showed that the amounts mobilised from the private sector by these mechanisms were highly concentrated in middle-income countries ( $72 \%$ of the total), with lower middle-income countries (LMICs) and upper middle-income countries (UMICs) receiving 32\% and $41 \%$ of the funds mobilised respectively (Figure 8). Only $8 \%$ of the amounts mobilised targeted least developed countries (LDCs), and 2.9\% other low-income countries (LICs). While guarantees represented the main mobilisation instrument in LDCs and other LICs, syndicated loans were also significant in middle-income countries (36\% in UMICs). Shares in CIVs played an important role (58\%) in funds with regional and multi-country character, classified as unallocated.

Figure 8. By income group, USD billion

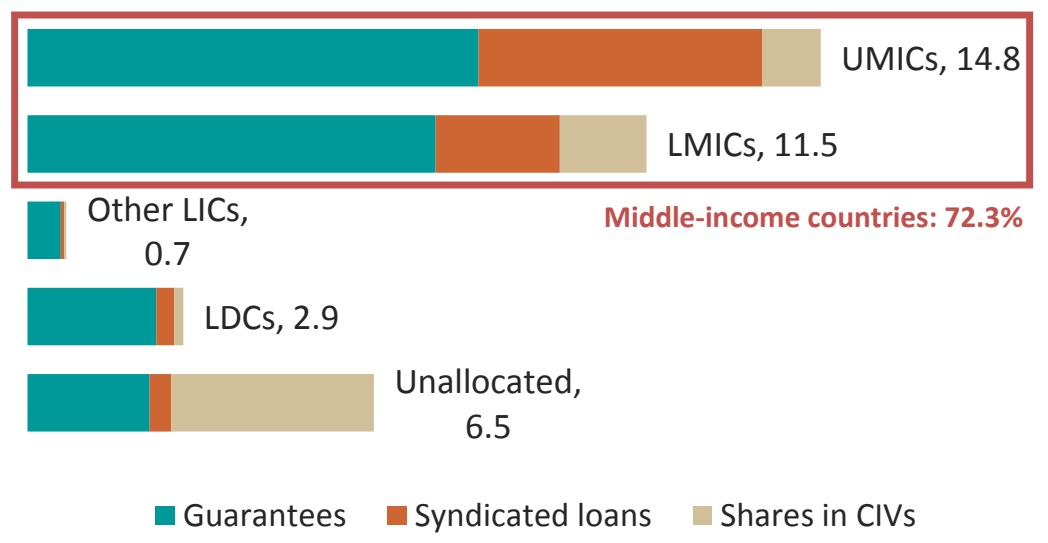

\section{Breakdown by sector: Private finance mobilised mainly targeted the banking and infrastructure sectors}

As shown in Figure 9, a majority of the private funds mobilised benefited the energy, industry and banking sectors $(30 \%, 22 \%$ and $19 \%$ respectively).

In general, guarantees remained the main mobilisation tool in most sector categories. They were particularly prominent in the water and sanitation sector (representing more than $71 \%$ ), health $(64 \%)$ and industry (61\%). Shares in CIVs were a major mobilisation tool in the banking sector (35\%), while in other sectors they seemed to play a marginal role. Syndicated loans were used in almost all sectors, and more significantly in the energy, industry, transport, water and sanitation and agriculture sectors. 
Figure 9. Finance mobilised per sector by instrument, USD billion

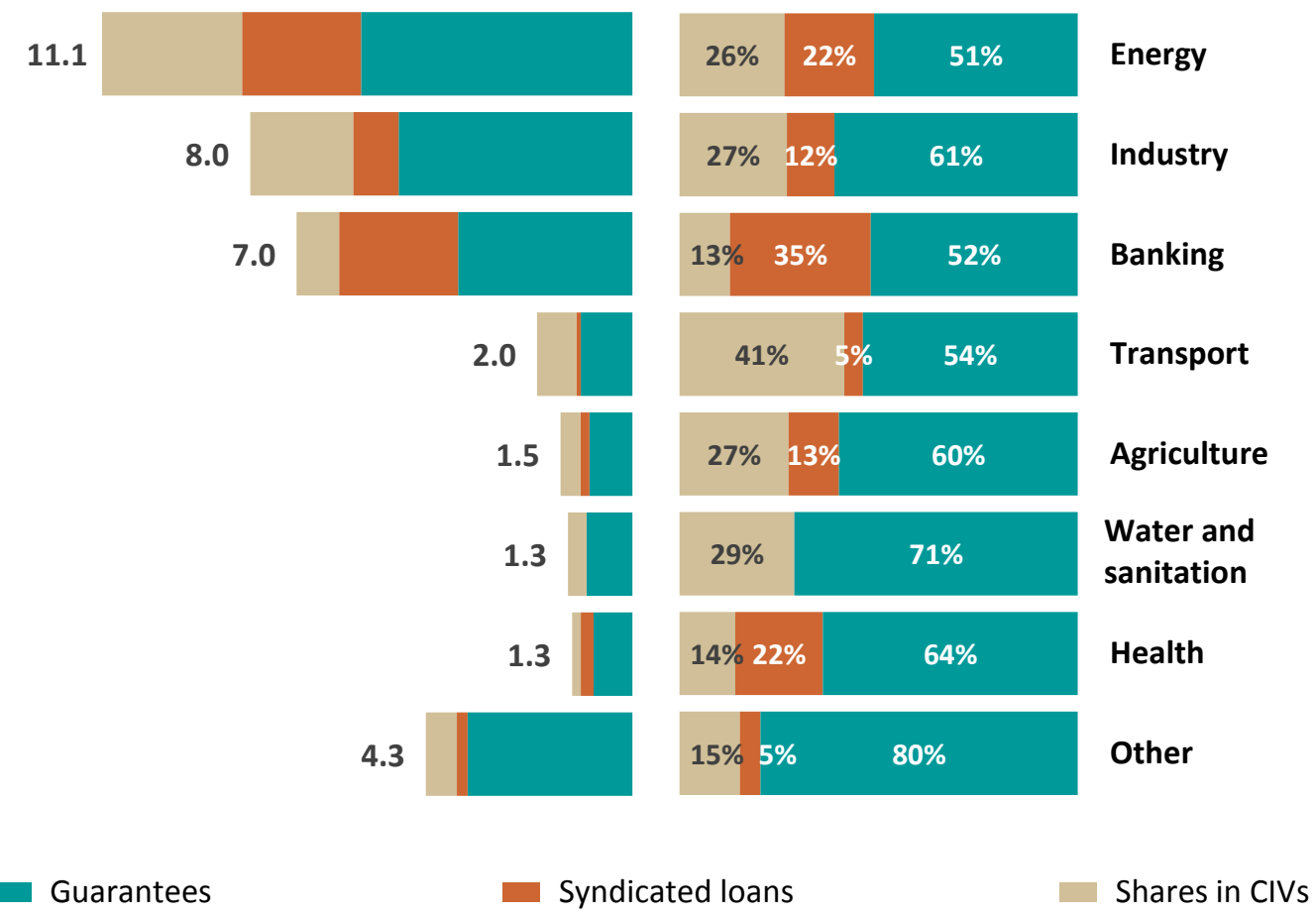

\section{Climate focus: $19 \%$ of the amounts mobilised were climate-related}

According to the Survey, 19\% (i.e. USD 6.8 billion) of the amounts mobilised from the private sector by guarantees, syndicated loans and shares in CIVs in 2012-14 were labelled as climate-related ${ }^{7}$ (Figure 10), in particular targeting climate change mitigation only (71\%). Around $27 \%$ addressed both climate change mitigation and adaptation objectives and $2 \%$ was labelled as targeting climate change adaptation only. Although six responding institutions did not include climate reporting in their data submission, the data revealed that these respondents also operated in climate-related sectors. For example, amounts mobilised by these institutions for renewable energy projects added up to USD 3.5 billion, corresponding to $9.7 \%$ of the total amount mobilised.

The main mobilisation instrument in climate-related finance was guarantees $(51 \%)$, but a significant share was also leveraged through syndicated loans (38\%). Shares in CIVs amounted $10 \%$ of the amount labelled as climate-related.

As Figure 11 shows, $31 \%$ of all syndicated loans, $16 \%$ of all guarantees and $11 \%$ of all shares in CIVs were climate-related.

7. Both the Rio Marker methodology and MDB component approach were used for the purpose of the Survey.

PRIVATE FINANCE MOBILISATION BY OFFICIAL DEVELOPMENT FINANCE INTERVENTIONS

Guarantees, syndicated loans and collective investment vehicles 
Figure 10. Climate-related private finance mobilised

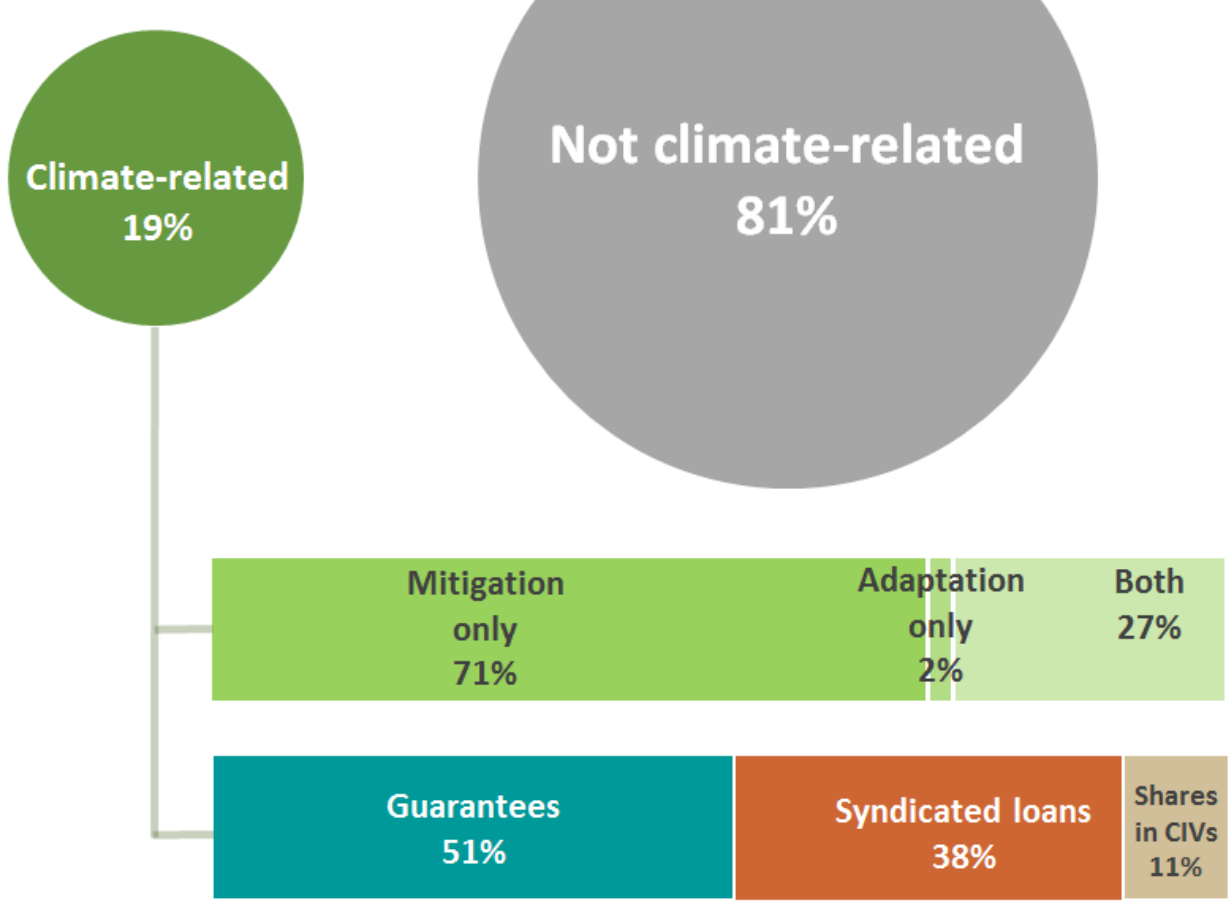

Figure 11. Climate finance per instrument

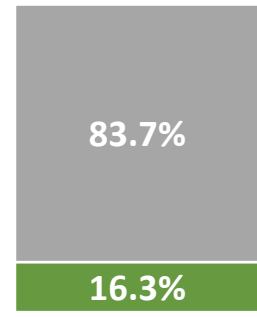

Guarantees

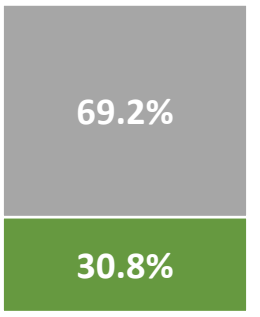

Syndicated loans

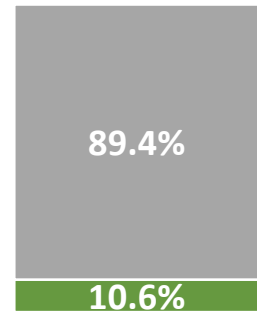

Shares in CIVs

- Climate-related $\quad$ Not climate-related 


\section{IIII. CONCLUSION AND NEXT STEPS}

One of the main objectives of the Survey was to collect comprehensive data on amounts mobilised from the private sector through guarantees, syndicated loans and shares in CIVs over the period 2012-14, while piloting recently agreed methodologies. Based on the responses and quality of the data received, it can be concluded that the Survey had encouraging results and demonstrated the feasibility to measure and collect data on the mobilisation effect of official development finance interventions, at least for the three instruments surveyed. Work is underway to adjust the DAC reporting directives to incorporate the data collection on amounts mobilised in the regular reporting as from 2017.

To this end, the DAC, in close collaboration with DFIs and the OECD-led Research Collaborative, has already initiated methodological work to track and measure amounts mobilised through a larger range of leveraging instruments, notably credit lines, stand-alone loans, structured finance and mezzanine finance. The new methodologies will be developed following key principles underpinning an international statistical system (see Annex 3). In other words, in order to be realistic and feasible the new methodologies will strive to be i) conservative in terms of causality, ii) fair in terms of attribution and iii) pragmatic in terms of point of measurement and data availability.

So far, discussions and consultations with partner institutions have highlighted a number of challenges that will need to be addressed which include:

- For credit lines - a key feature of this instrument is that the mobilisation effect occurs at different stages of the financial process: i) when private co-investments are stipulated in the credit line contract (at the institution or/and intermediary level - i.e. top-up loans), ii) on a revolving basis, according to an institution-specific factor that needs to be determined.

- For direct investment in companies - a key principle is that investments cannot be assessed independently without taking into account the other layers of capital in the balance sheet, i.e. equity and debt. Another challenge is to define the time period during which a causal link can be established between the entry into the company's or fund's capital of the different types of investors (official and private). To facilitate the development of a realistic methodology, assumptions may need to be developed to estimate the fundraising period, if applicable (following the same approach as for common shares and shares in the riskiest tranche of CIVs, see Annex 4).

- For structured finance - some financial deals can be extremely complex, combining multiple leveraging instruments (e.g. guarantees and loan syndications). This makes the causal links and attribution methods more difficult to establish. To be pragmatic and feasible, the approach followed could be to apply a pure pro-rata attribution method at the financial closure stage of the project (or project phase), i.e. when all the financing agreements have been signed.

- In the case of standard loans in co-financing - the main challenge relates to the boundaries of the project (the notion of total project cost varies among institutions), which is key to avoid double counting and, at the same time, ensure a fair attribution among co-financiers. 


\section{ANNEX 1. AMOUNTS MOBILISED BY INSTITUTION}

\begin{tabular}{|c|c|c|c|c|c|c|c|}
\hline & \multirow[b]{2}{*}{ Institution } & \multirow[b]{2}{*}{ Responses } & \multirow{2}{*}{$\begin{array}{l}\text { Climate } \\
\text { reporting }\end{array}$} & \multicolumn{4}{|c|}{ Amounts mobilised in 2012-14, USD billion } \\
\hline & & & & Guarantees & $\begin{array}{l}\text { Syndicated } \\
\text { Loans }\end{array}$ & $\begin{array}{l}\text { Shares } \\
\text { in CIVs }\end{array}$ & Total \\
\hline \multirow{36}{*}{ 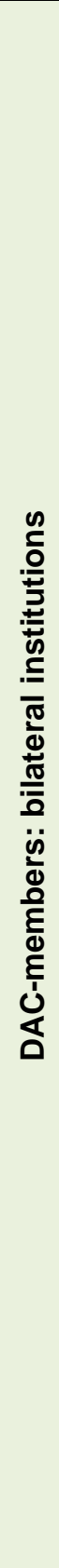 } & Australia (AusAID) & No data & No & & & & \\
\hline & Austria (ADA) & No data & No & & & & \\
\hline & Austria (OeEB) & No data & No & & & & \\
\hline & Belgium (BIO) & Yes & Yes & & 16.7 & 0.9 & 17.6 \\
\hline & Belgium (DGCD) & No data & No & & & & \\
\hline & Canada (Dpt of FATD) & Yes & Yes & & & 34.3 & 34.3 \\
\hline & Canada (Finance Canada) & Yes & Yes & & & 13.1 & 13.1 \\
\hline & Czech Republic (CzDA) & No data & No & & & & \\
\hline & Denmark (DANIDA) & No response & No & & & & \\
\hline & Denmark (IFU ) & Yes & Yes & 0.9 & & 253.9 & 254.8 \\
\hline & Finland (Finnfund) & Yes & Yes & & 1.0 & 66.5 & 67.5 \\
\hline & Finland (MFA ) & No data & No & & & & \\
\hline & France (AFD) & Yes & No & 938.6 & & & 938.6 \\
\hline & France (Proparco) & Yes & No & & 116.0 & 591.1 & 707.1 \\
\hline & Germany (KfW) & Yes & Yes & 30.0 & & 220.6 & 250.6 \\
\hline & Germany (DEG) & No data & No & & & & \\
\hline & Greece (MFA ) & No data & No & & & & \\
\hline & Iceland (ICEIDA) & No response & No & & & & \\
\hline & Ireland (DFAT) & No response & No & & & & \\
\hline & Italy (DGCS) & No data & No & & & & \\
\hline & Italy (Artigiancassa) & No data & No & & & & \\
\hline & Italy (SIMEST) & No data & No & & & & \\
\hline & Japan (JICA) & Yes & Yes & & & 80.0 & 80.0 \\
\hline & Japan (JBIC) & No data & No & & & & \\
\hline & Korea (KOICA) & No data & No & & & & \\
\hline & Korea (KEXIM) & No data & No & & & & \\
\hline & Luxembourg (MFA ) & No response & No & & & & \\
\hline & Netherlands (FMO) & Yes & No & & 680.3 & & 680.3 \\
\hline & Netherlands (MFA) & No data & No & & & & \\
\hline & New Zealand (NzAid) & No response & No & & & & \\
\hline & Norway (Norfund) & Yes & Yes & & & 103.8 & 103.8 \\
\hline & Norway (NORAD) & No data & No & & & & \\
\hline & Poland (MFA) & No response & No & & & & \\
\hline & Portugal (SOFID) & Yes & Yes & 21.3 & & & 21.3 \\
\hline & Portugal (Government) & No data & No & & & & \\
\hline & Slovak Republic (SAMRS) & No data & No & & & & \\
\hline
\end{tabular}




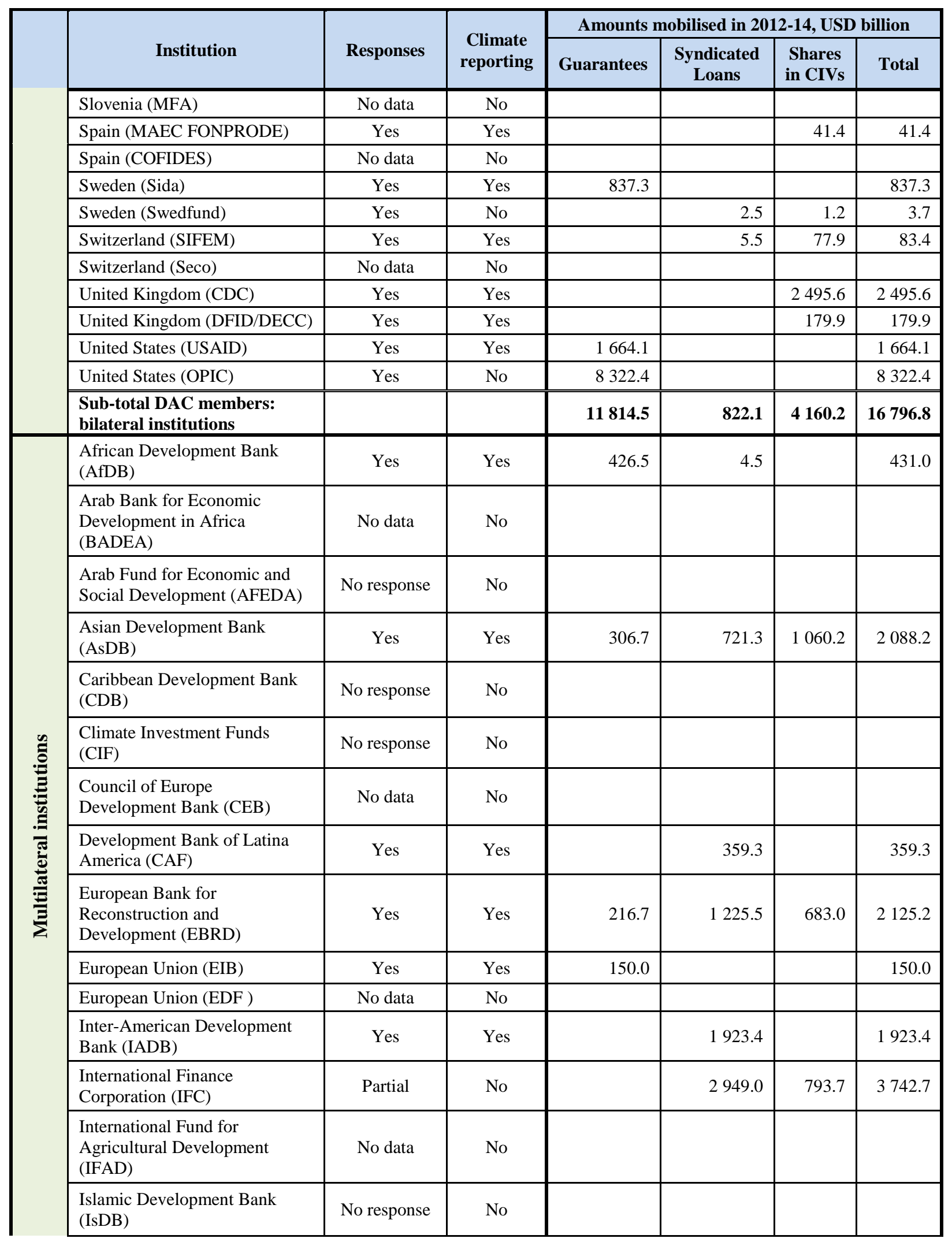




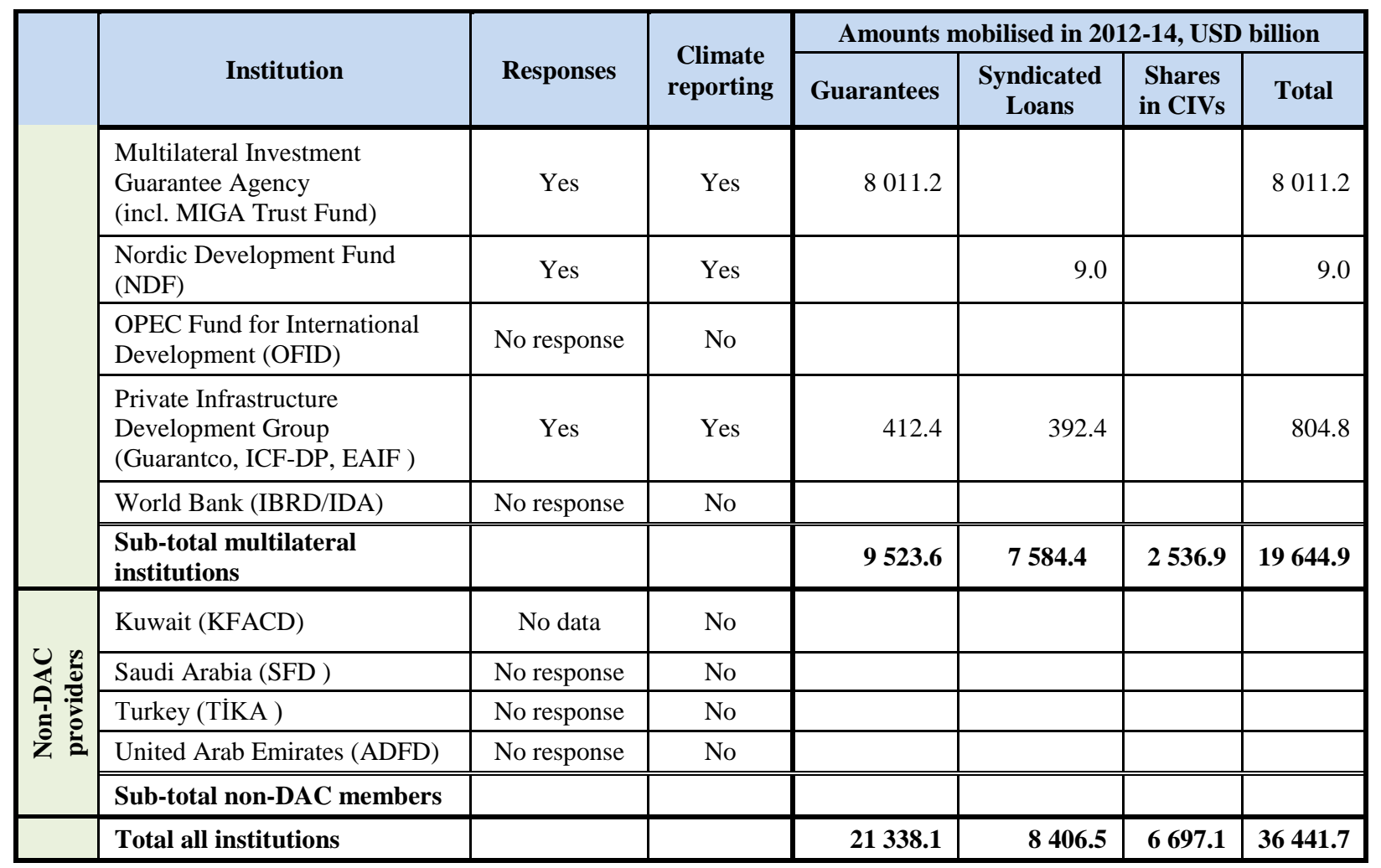




\section{ANNEX 2. AMOUNTS MOBILISED BY RECIPIENT COUNTRY}

\begin{tabular}{|c|c|c|c|c|c|}
\hline \multirow{2}{*}{ Region } & \multirow{2}{*}{ Recipient country } & \multicolumn{4}{|c|}{ Amount mobilised in 2012-2014, USD million } \\
\hline & & Guarantees & Syndicated loans & Shares in CIVs & Total \\
\hline \multirow{38}{*}{ 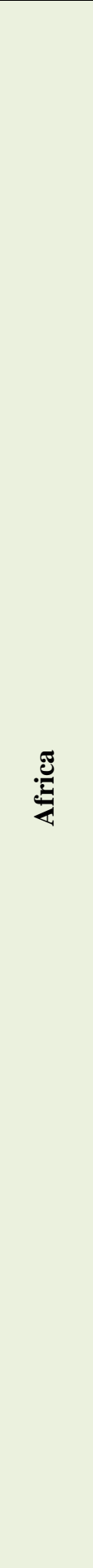 } & Egypt & 401.4 & & & 401.4 \\
\hline & Libya & 13.0 & & & 13.0 \\
\hline & Morocco & 65.9 & 3.3 & 18.6 & 87.8 \\
\hline & Tunisia & 302.5 & 2.0 & 1.1 & 305.6 \\
\hline & North of Sahara, regional & & & 4.5 & 4.5 \\
\hline & Angola & 721.5 & & & 721.5 \\
\hline & Benin & 27.8 & & & 27.8 \\
\hline & Botswana & 27.1 & & & 27.1 \\
\hline & Burkina Faso & 25.2 & & & 25.2 \\
\hline & Burundi & 12.1 & & & 12.1 \\
\hline & Cameroon & 563.4 & & & 563.4 \\
\hline & Chad & 49.6 & & & 49.6 \\
\hline & Côte d'Ivoire & 1058.1 & 69.0 & & 1127.1 \\
\hline & $\begin{array}{l}\text { Democratic Republic of the } \\
\text { Congo }\end{array}$ & 106.0 & 25.5 & 0.0 & 131.5 \\
\hline & Ethiopia & 29.5 & 35.0 & 32.5 & 97.1 \\
\hline & Gabon & 74.9 & & & 74.9 \\
\hline & Ghana & 839.8 & 170.2 & & 1010.1 \\
\hline & Guinea & 30.2 & 11.0 & & 41.2 \\
\hline & Kenya & 622.7 & 60.0 & 33.4 & 716.1 \\
\hline & Liberia & 1.0 & & & 1.0 \\
\hline & Madagascar & 105.9 & & & 105.9 \\
\hline & Malawi & 4.3 & & & 4.3 \\
\hline & Mali & 40.7 & & & 40.7 \\
\hline & Mauritania & 3.9 & & & 3.9 \\
\hline & Mauritius & 9.7 & & 4.5 & 14.2 \\
\hline & Mozambique & 48.1 & 12.0 & 4.5 & 64.6 \\
\hline & Namibia & 5.3 & & & 5.3 \\
\hline & Niger & 16.3 & & & 16.3 \\
\hline & Nigeria & 622.2 & 123.9 & 24.0 & 770.1 \\
\hline & Rwanda & 101.3 & & 0.6 & 101.9 \\
\hline & Senegal & 234.6 & & & 234.6 \\
\hline & Sierra Leone & 3.4 & & & 3.4 \\
\hline & South Africa & 536.6 & 33.5 & 166.0 & 736.1 \\
\hline & South Sudan & 11.7 & & & 11.7 \\
\hline & Sudan & - & 0.4 & & 0.4 \\
\hline & Tanzania & 43.1 & 90.0 & 4.5 & 137.6 \\
\hline & Togo & 25.6 & & & 25.6 \\
\hline & Uganda & 54.6 & & 48.3 & 102.9 \\
\hline
\end{tabular}

PRIVATE FINANCE MOBILISATION BY OFFICIAL DEVELOPMENT FINANCE INTERVENTIONS

Guarantees, syndicated loans and collective investment vehicles 


\begin{tabular}{|c|c|c|c|c|c|}
\hline \multirow{7}{*}{ Region } & \multirow{2}{*}{ Recipient country } & \multicolumn{4}{|c|}{ Amount mobilised in 2012-2014, USD million } \\
\hline & & Guarantees & Syndicated loans & Shares in CIVs & Total \\
\hline & Zambia & 234.1 & 1.0 & & 235.1 \\
\hline & Zimbabwe & - & & 8.5 & 8.5 \\
\hline & South of Sahara, regional & 10.6 & & 23.2 & 33.7 \\
\hline & Africa, regional & 976.3 & & 1527.2 & 2503.4 \\
\hline & Sub-total Africa & 8060.0 & 636.7 & 1901.5 & 10598.2 \\
\hline \multirow{23}{*}{ 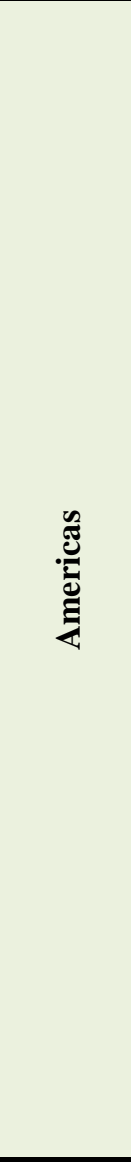 } & Costa Rica & 71.4 & 590.2 & 2.4 & 664.0 \\
\hline & Dominican Republic & & 10.0 & & 10.0 \\
\hline & El Salvador & 135.3 & 3.1 & 0.3 & 138.7 \\
\hline & Guatemala & 312.3 & 103.0 & & 415.3 \\
\hline & Haiti & 38.4 & & & 38.4 \\
\hline & Honduras & 148.0 & 44.7 & 2.5 & 195.2 \\
\hline & Jamaica & 23.1 & & & 23.1 \\
\hline & Mexico & 354.8 & 428.1 & & 782.9 \\
\hline & Nicaragua & 59.0 & 3.0 & 10.0 & 72.1 \\
\hline & Panama & 713.8 & 0.1 & & 713.8 \\
\hline & $\begin{array}{l}\text { North \& Central America, } \\
\text { regional }\end{array}$ & & & 4.1 & 4.1 \\
\hline & Argentina & & 360.0 & & 360.0 \\
\hline & Bolivia & 10.8 & 1.0 & & 11.8 \\
\hline & Brazil & 455.1 & 517.9 & 75.8 & 1048.8 \\
\hline & Chile & 936.4 & 509.0 & & 1445.4 \\
\hline & Colombia & 212.0 & 142.5 & 188.2 & 542.7 \\
\hline & Ecuador & 19.3 & 121.4 & & 140.7 \\
\hline & Paraguay & & 72.5 & & 72.5 \\
\hline & Peru & 262.3 & 154.6 & 21.7 & 438.6 \\
\hline & Uruguay & & 79.2 & & 79.2 \\
\hline & South America, regional & & & 0.4 & 0.4 \\
\hline & America, regional & 130.7 & 345.0 & 33.3 & 509.0 \\
\hline & Sub-total America & 3882.7 & 3485.2 & 338.7 & 7706.6 \\
\hline \multirow{12}{*}{$\frac{\sqrt[\pi]{\pi}}{4}$} & Cambodia & 34.2 & 11.7 & & 45.9 \\
\hline & China (People's Republic of) & 58.2 & 977.4 & 21.0 & 1056.6 \\
\hline & Indonesia & 124.7 & 479.8 & 19.8 & 624.3 \\
\hline & $\begin{array}{l}\text { Lao People's Democratic } \\
\text { Republic }\end{array}$ & 1.1 & 133.3 & & 134.4 \\
\hline & Malaysia & 250.0 & & & 250.0 \\
\hline & Mongolia & & 160.4 & 67.4 & 227.8 \\
\hline & Philippines & 95.0 & & 600.0 & 695.0 \\
\hline & Thailand & 32.5 & & & 32.5 \\
\hline & Viet Nam & 717.7 & & 92.8 & 810.4 \\
\hline & Far East Asia, regional & & & 27.5 & 27.5 \\
\hline & Iraq & 52.1 & & & 52.1 \\
\hline & Jordan & 760.1 & 269.3 & & 1029.4 \\
\hline
\end{tabular}

PRIVATE FINANCE MOBILISATION BY OFFICIAL DEVELOPMENT FINANCE INTERVENTIONS

Guarantees, syndicated loans and collective investment vehicles 


\begin{tabular}{|c|c|c|c|c|c|}
\hline \multirow{23}{*}{ Region } & \multirow{2}{*}{ Recipient country } & \multicolumn{4}{|c|}{ Amount mobilised in 2012-2014, USD million } \\
\hline & & Guarantees & Syndicated loans & Shares in CIVs & Total \\
\hline & Lebanon & 60.5 & & 97.8 & 158.4 \\
\hline & West Bank and Gaza Strip & 55.4 & & & 55.4 \\
\hline & Yemen & 0.3 & & & 0.3 \\
\hline & Middle East, regional & 150.0 & & & 150.0 \\
\hline & Afghanistan & 108.8 & & & 108.8 \\
\hline & Armenia & 25.7 & 14.0 & & 39.7 \\
\hline & Azerbaijan & 27.8 & 49.9 & & 77.7 \\
\hline & Bangladesh & 257.6 & 13.0 & & 270.7 \\
\hline & Georgia & 57.6 & 195.8 & 57.7 & 311.1 \\
\hline & India & 474.4 & 215.2 & 588.4 & 1278.0 \\
\hline & Kazakhstan & 48.2 & 109.2 & 52.5 & 209.9 \\
\hline & Kyrgyzstan & 4.3 & & & 4.3 \\
\hline & Myanmar & & & 80.0 & 80.0 \\
\hline & Nepal & 30.0 & 5.9 & 0.1 & 36.0 \\
\hline & Pakistan & 1190.4 & 22.5 & & 1212.9 \\
\hline & Sri Lanka & 25.0 & 158.1 & & 183.1 \\
\hline & Tajikistan & 3.8 & & & 3.8 \\
\hline & Turkmenistan & 8.7 & & & 8.7 \\
\hline & Uzbekistan & 236.5 & & & 236.5 \\
\hline & Asia, regional & & & 510.6 & 510.6 \\
\hline & Sub-total Asia & 4890.3 & 2815.7 & 2215.7 & 9921.6 \\
\hline \multirow{12}{*}{$\underset{:}{0}$} & Albania & 219.9 & 103.3 & 0.7 & 323.9 \\
\hline & Belarus & & 34.2 & & 34.2 \\
\hline & Bosnia and Herzegovina & 129.0 & & 0.7 & 129.7 \\
\hline & $\begin{array}{l}\text { Former Yugoslav Republic of } \\
\text { Macedonia }\end{array}$ & 191.3 & 8.4 & 0.6 & 200.3 \\
\hline & Kosovo & 26.0 & & & 26.0 \\
\hline & Moldova & 32.7 & 2.0 & 4.4 & 39.1 \\
\hline & Montenegro & & & 0.7 & 0.7 \\
\hline & Serbia & 1148.4 & 51.8 & 11.3 & 1211.6 \\
\hline & Turkey & 1412.5 & 737.3 & 444.0 & 2593.8 \\
\hline & Ukraine & 319.8 & 422.8 & 132.4 & 875.0 \\
\hline & Europe, regional & 60.0 & & & 60.0 \\
\hline & Sub-total Europe & 3539.5 & 1359.8 & 594.9 & 5494.1 \\
\hline \multirow{2}{*}{ 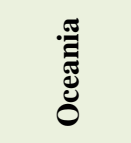 } & Papua New Guinea & 10.3 & 50.0 & & 60.3 \\
\hline & Sub-total Oceania & 10.3 & 50.0 & & 60.3 \\
\hline 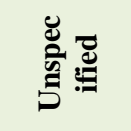 & Bilateral, unspecified & 955.3 & 59.1 & 1646.4 & 2660.8 \\
\hline \multicolumn{2}{|l|}{ Total } & 21338.1 & 8406.5 & 6697.1 & 36441.7 \\
\hline
\end{tabular}




\section{ANNEX 3. MEASURING MOBILISATION IN AN INTERNATIONAL STATISTICAL SYSTEM}

This annex summarises some of the main principles followed by the DAC while developing methodologies to capture amounts mobilised from the private sector as a result of public sector interventions. In particular, the note focuses on how these amounts could be captured in an international statistical system such as the Development Assistance Committee's (DAC).

With regard to the question of "how to measure", the issues of causality, attribution and point of measurement are carefully examined. The feasibility of the measurement is assessed in terms of data availability at the institutional level.

The note is based on the main findings from the Survey on guarantees for development carried out in 2013, the Survey on the mobilisation effect of official development finance carried out in 2014, and the results of a series of consultations with members and DFIs, including a working session with DFI experts held in Paris in July $2014 .^{8}$ The Surveys' sample includes aid agencies, bilateral and multilateral DFIs.

\section{How to measure?}

Methodologies to measure amounts mobilised vary among institutions; however common characteristics for most of them include: i) the use of the total project cost as a proxy for the amounts mobilised, ii) the inclusion of both official and private finance mobilised in the calculations, and iii) the need for subjective judgements, in particular to define causality (i.e. what would have happened if the official intervention had not been in place). Institutions with more elaborated calculations have a methodology that varies according to the financial instrument/mechanism being used. However, not all financial instruments in their portfolio are included in the calculations (e.g. equity investments are often excluded).

While thinking about a methodology to capture amounts mobilised in an international statistical system, such as the DAC's, three questions come immediately to mind:

1. Causality - Would the private financier have invested in the project without the official investment?

2. Attribution - If more than one official agency is involved in the project, how much did each of them mobilise?

3. Point of measurement - When are funds counted as mobilised? At the commitment or disbursement stages? What about private finance invested in the project in subsequent years?

\section{Causality}

As mentioned above, some subjectivity is embedded in most methodologies used at the institutional level, in particular to assess causality. This is because measuring causality statistically can be extremely complex as evidence that the private financiers would not have invested without the official investment is usually unavailable. ${ }^{9}$ In order to avoid double-counting in an international statistical system, assumptions - or

8. Working session with DFIs' experts on tracking and valorising DFIs' operations in the post-2015 DAC statistical framework, Paris, 15-16 July 2014.

9 One exception is the case of fee-based services to mobilise finance. This is because the payment of the fee by the client is a formal recognition that the institution charging the fee has mobilised the funds, and thus a proof of causality. IFC has a methodology - referred as "core mobilisation" - to track the amounts mobilised by such services. 
"common subjectivity" - are needed to ensure that every institution reports with the same understanding of what and how much can be recorded as being mobilised.

In the view of the Secretariat and the DFI experts, assumptions to measure mobilisation should reflect reality, be conservative (to avoid double counting), be commonly agreed and applied in reporting, and vary according to the financial instrument/mechanism being used.

Based on the Surveys' findings, mechanisms could be classified into two broad categories: i) those for which the amount mobilised is a concrete amount that can be defined; and ii) those for which the amount mobilised has to be proxied by the total project cost, a measure with vague boundaries and a varying definition, even within institutions. Conservative and measurable assumptions seem feasible for the first category only. Mechanisms in the first category include syndicated loans, guarantees and shares in collective investment vehicles. Mechanisms in the second category include direct equity investments, mezzanine finance, investment grants and parallel co-financing.

\section{Attribution}

Whenever more than one official investor is involved in a project having mobilised private finance, the issue of attribution - i.e. how much each official investor mobilised - arises. A clear attribution of private finance mobilised is key to avoid double-counting.

Pro-rata attribution based on the amounts invested by each official agency is, mathematically, the simplest approach. However, it does not take into account certain characteristics (e.g. a more active role by one of the official agencies, different risk levels born by each official body) that, if possible to prove, would allow a better reflection of reality. An example of this is a loan syndication, in which the arranger has a proven more active role in the transaction, and could therefore be attributed a higher portion of the amounts mobilised than other official participants in the syndication.

\section{Point of measurement}

Data on commitments are more readily available than data on disbursements at the institutional level. The estimation of the amount mobilised could be thus based on commitments.

In terms of the timing of funds, the DFI experts highlighted that the measurement of amounts mobilised may need to be limited to private resources committed during the year of the official investment, as trying to include private investments in subsequent years may result in complex calculations.

\section{Data availability for reporting: is it feasible?}

Most institutions are trying to estimate the amount mobilised by their operations: even if data on amounts mobilised are not always systematically collected in their statistical systems (and are thus not ready for reporting), data on amounts mobilised are often available in project documentation. However, some data are more available than others. Data on the face value of the loan guaranteed by the institution, on the total amount of private investments in syndications, and on private investments in investment funds are often available. On the contrary, data on the amount mobilised by equity or mezzanine investments are more difficult to obtain. Data on the total project cost seem also to be available, however many DFIs highlighted the low quality of these data. They mentioned that data on the total project cost were often a supplementary field in their systems, subject to the project manager interpretation of the project boundaries.

Distinction between official and private flows mobilised is available in most statistical systems (or project documents); however the understanding of what is official and what is private may differ among institutions. 


\section{ANNEX 4. MOBILISATION INSTRUMENTS METHODOLOGIES}

This annex provides definitions and simple examples for the mobilisation instruments covered by this Survey.

Guarantees refer to legally binding agreements under which the guarantor agrees to pay part or the entire amount due on a loan, equity or other instrument in the event of non-payment by the obligor or loss of value in case of investment.

Figure 12 below shows an example of a guarantee scheme. Imagine a USD 10 million project receiving a loan of USD 4 million from Lender 1 - a private investor from the recipient country - and equity from Investor 1 for USD 6 million. Lender 1 benefits from an official guarantee covering up to 70\% (USD 2.8 million) of the loan. The amount mobilised by the guarantee is USD 4 million. The assumption is that a private investor would not have invested without the guarantee provided by an official institution.

Figure 13. Example of a guarantee scheme

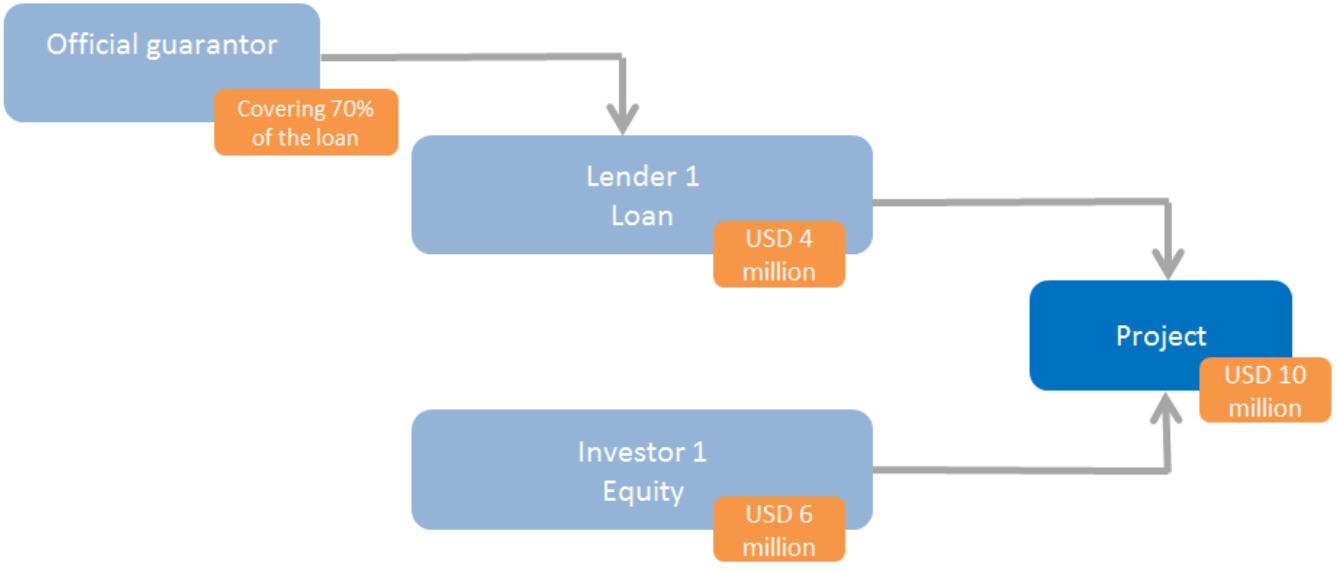

Syndicated loans are defined as loans provided by a group of lenders (called a syndicate) who work together to provide funds for a single borrower. The main objective is to spread the risk of a borrower default across multiple lenders, and thus encourage private investment. A syndicated loan arranged by an official institution may include financing from the market through the so-called " $\mathrm{A} / \mathrm{B}$ loan" structure. The official institution often retains a portion of the loan for its own account (A Loan), and sells participations in the remaining portion to other participants (B Loan). The borrower signs a single loan agreement with the lender of record. Official arrangers may also seek to syndicate "parallel loans" from other official international financial institutions (e.g. IFIs) and other participants that are not eligible participants for Bloans. In these cases, the official arranger identifies investments, structures deals, and negotiates with the borrower in coordination with all parallel lenders. The implicit assumption is that the private sector would not have invested in the CIV without the official investment in the riskiest tranche (common equity in this example).

Example below (Figure 14) illustrates a typical syndicated loan where an official institution (e.g. a DFI) provides a parallel loan of USD 5 million (Lender 1), and a private investor from an OECD country provides the B loan of USD 7 million (Lender 2). In this example, the public arranger commits USD 10 million. The amount mobilised from the private sector is USD 7 million. 
Figure 14. Example of a syndicated loan

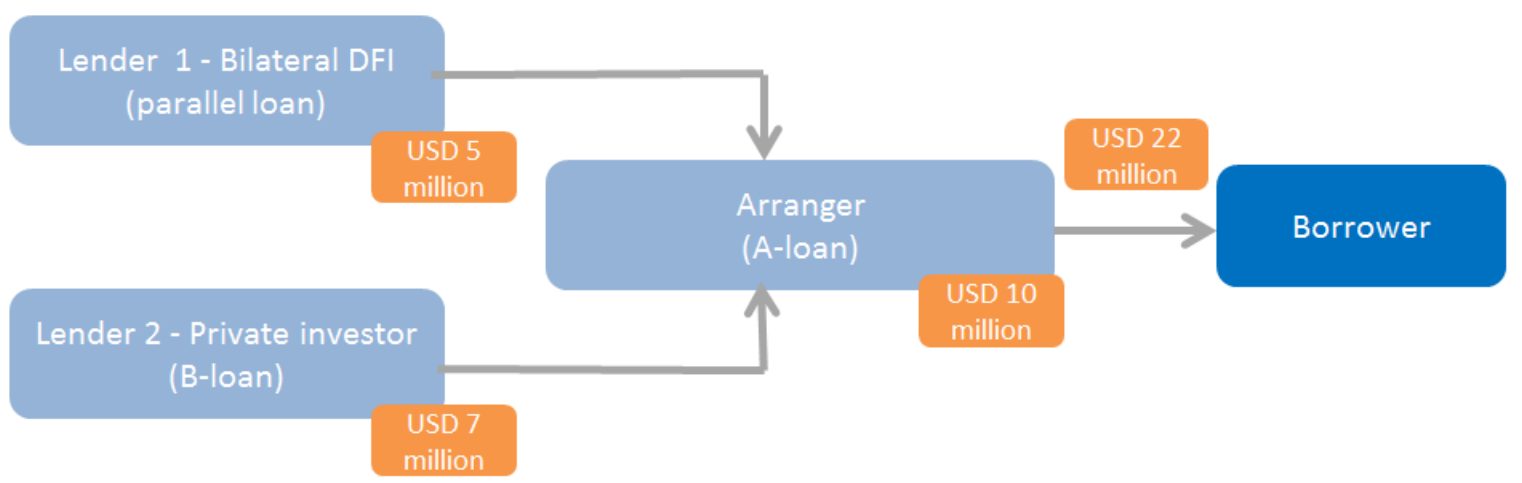

Shares in collective investment vehicles (CIVs) are those invested in entities that allow investors to pool their money and jointly invest in a portfolio of companies. A CIV can either have a flat structure - in which investment by all participants has the same profile with respect to risks, profits and losses - or have its capital divided in tranches with different risk and return profiles, e.g. by different order of repayment entitlements (seniority), different maturities (locked-up capital versus redeemable shares) or other structuring criteria. Moreover, CIVs can be close- or open-ended. Close-ended CIVs have a limited period of time during which new investments in the CIV may be made (fund-raising period), while open-ended CIVs can issue and redeem shares at any time. The assumption is that private investors (including the arranger) would not have invested without the presence of official participants in the syndication.

Table 1 below shows an example of an amount mobilised through shares in CIVs. Imagine a flat, openended CIV, whose inception date was on 15 September 2008, where two official investors - DFI 1 and DFI 2 - invest USD 10 million and USD 4 million respectively in October 2008, a private investor from the beneficiary country invests USD 6 million in June 2012, one official institution (DFI 3) invests USD 12 million in January 2013 and a private investor from a third high income country invests USD 8 million in April 2013 (Table 1 below). The amount mobilised from the private sector during the fund-raising period is USD 14 million, of which USD 6 million in 2012 and USD 8 million in 2013.

Table 1: Investments in the CIV (USD thousand)

\begin{tabular}{|c|c|c|c|c|}
\hline $\begin{array}{r}\text { Investment } \\
\text { year }\end{array}$ & $\begin{array}{c}\text { October } \\
\mathbf{2 0 0 8}\end{array}$ & $\begin{array}{c}\text { June } \\
\mathbf{2 0 1 2}\end{array}$ & $\begin{array}{c}\text { January } \\
\mathbf{2 0 1 3}\end{array}$ & April 2013 \\
\hline Investors & 10000 & & & \\
\hline DFI 1 & 4000 & & & \\
\hline DFI 2 & & & 12000 & \\
\hline Private investor 1 & & 6000 & & 8000 \\
\hline Private investor 2 & & & & $\mathbf{8 0 0 0}$ \\
\hline \hline Total investments & 14000 & $\mathbf{6 0 0 0}$ & $\mathbf{1 2 0 0 0}$ & \\
\hline
\end{tabular}




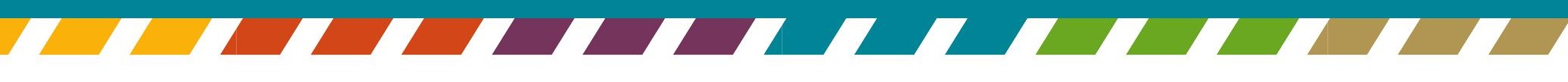

